\title{
A Late Miocene Pipine Frog From The Urumaco Formation, Venezuela
}

\author{
Delfino, Massimo ; Sánchez-Villagra, Marcelo
}

\begin{abstract}
THE PIPIDAE currently hosts about 35 species, with a disjoint Gondwanan distribution that only in the last decades, due to human introduction of the African Xenopus in four continents, expanded into Laurasian countries where this frog is often regarded as a pest (Tinsley et al., 2015). The extant pipid genera can be grouped into two clades, Pipinae and Xenopodinae, whose content varies according to different phylogenetic analyses. The molecular approach favours in most cases the inclusion of the sole Pipa in the Pipinae whereas the Xenopodinae host Xenopus (and, if not considered a synonym of the former, also Silurana) plus the Hymenochirini: Hymenochirus and Pseudhymenochirus (see literature cited in Cannatella, 2015). Conversely, the morphological approach generally suggests the inclusion of Pipa and the Hymenochirini in the Pipinae and Xenopus (plus Silurana) in the Xenopodinae (Gómez, 2016, and literature therein). Pipa is South American whereas both the Hymenochirini and the Xenopodinae are currently exclusive (not considering the above mentioned human introductions) of sub-Saharan Africa (Frost, 2017). The pipid fossil record, rather rich and with a much broader geographic range than that currently shown by extant species (Báez, 1996; Sanchiz, 1998; Gómez, 2016), consists mostly of Cretaceous and Paleogene remains that play a relevant role in the analysis of the earlier history of such disjoint - but at the same time possibly intertwined-distribution. South America hosted several taxa related to the crown Xenopodinae from the Cretaceous to the Late Pleistocene, but no Hymenochirini are recorded there (Gómez, 2016). The South American post-Paleogene record is remarkably scarce and Pipa has virtually no fossil record, except for the mention by Liais (1872) of an entire 'head' from the Pleistocene or Holocene of Rio das Velhas in Brazil (Rio Dal Belhas in Sanchiz, 1998). The material was reported to be identical in size and aspect to Pipa bimaculata (a species name that is currently not valid and not listed among the synonyms of Pipa by Frost, 2017). However, the fossil has not been further described or figured and was simply listed as Pipa sp. by Sanchiz (1998). Here we report on a pipid fossil from Corralito, a late Miocene locality in the Urumaco Basin, Venezuela. The Neogene localities in the Urumaco Basin have so far yielded a large number of marine and continental vertebrates belonging to several major clades (Sánchez-Villagra et al., 2010; Carrillo-Briceño et al., 2015) but amphibians had not been reported to date. Most of the continental taxa retrieved are large sized, some being 'gigantic', such as the crocodilians Gryposuchus and Purussaurus, the turtle Stupendemys and the rodent Phoberomys (among others, Sánchez- Villagra et al., 2010; Scheyer et al., 2013). Prospection in the Urumaco Basin carried out in November 2013 yielded few continental vertebrates of small size, including the single amphibian remain that is here described and discussed. Institutional acronyms: AMNH, American Museum of Natural History, New York; AMU-CURS, Colección de Paleontología de Vertebrados de la Alcaldía de Urumaco, Estado Falcón, Venezuela; MDHC, Massimo Delfino Herpetological Collection deposited at the Department of Earth Sciences, University of Turin, Italy; MLP, Museo de La Plata, La Plata, Argentina; MNHN, Muséum National d'Histoire Naturelle, Paris, France; PIMUZ, Paläontologisches Institut und Museum, Universität Zürich, Switzerland.
\end{abstract}

DOI: https://doi.org/10.5710/AMGH.04.10.2017.3136 
Posted at the Zurich Open Repository and Archive, University of Zurich

ZORA URL: https://doi.org/10.5167/uzh-151891

Journal Article

Published Version

Originally published at:

Delfino, Massimo; Sánchez-Villagra, Marcelo (2018). A Late Miocene Pipine Frog From The Urumaco Formation, Venezuela. Ameghiniana:210-214.

DOI: https://doi.org/10.5710/AMGH.04.10.2017.3136 


\title{
A LATE MIOCENE PIPINE FROG FROM THE URUMACO FORMATION, VENEZUELA
}

\author{
MASSIMO DELFINO ${ }^{1,2}$, AND MARCELO R. SÁNCHEZ-VILLAGRA ${ }^{3}$
}

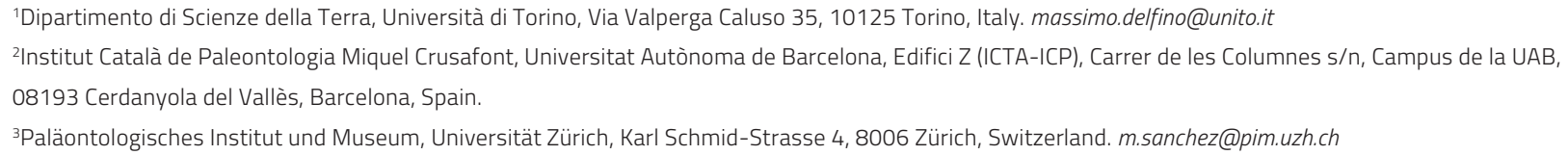

Key words. Pipa pipa. Biogeography. Neogene. Amazon. Urostyle. Sacrum. Fossil.

THE PIPIDAE currently hosts about 35 species, with a disjoint Gondwanan distribution that only in the last decades, due to human introduction of the African Xenopus in four continents, expanded into Laurasian countries where this frog is often regarded as a pest (Tinsley et al., 2015). The extant pipid genera can be grouped into two clades, Pipinae and Xenopodinae, whose content varies according to different phylogenetic analyses. The molecular approach favours in most cases the inclusion of the sole Pipa in the Pipinae whereas the Xenopodinae host Xenopus (and, if not considered a synonym of the former, also Silurana) plus the Hymenochirini: Hymenochirus and Pseudhymenochirus (see literature cited in Cannatella, 2015). Conversely, the morphological approach generally suggests the inclusion of Pipa and the Hymenochirini in the Pipinae and Xenopus (plus SiIurana) in the Xenopodinae (Gómez, 2016, and literature therein). Pipa is South American whereas both the Hymenochirini and the Xenopodinae are currently exclusive (not considering the above mentioned human introductions) of sub-Saharan Africa (Frost, 2017). The pipid fossil record, rather rich and with a much broader geographic range than that currently shown by extant species (Báez, 1996; Sanchiz, 1998; Gómez, 2016), consists mostly of Cretaceous and Paleogene remains that play a relevant role in the analysis of the earlier history of such disjoint-but at the same time possibly intertwined-distribution. South America hosted several taxa related to the crown Xenopodinae from the Cretaceous to the Late Pleistocene, but no Hymenochirini are recorded there (Gómez, 2016). The South American post-Paleogene record is remarkably scarce and Pipa has virtually no fossil record, except for the mention by Liais (1872) of an entire 'head' from the Pleistocene or Holocene of Rio das Velhas in Brazil (Rio Dal Belhas in Sanchiz, 1998). The material was reported to be identical in size and aspect to Pipa bimaculata (a species name that is currently not valid and not listed among the synonyms of Pipa by Frost, 2017). However, the fossil has not been further described or figured and was simply listed as Pipa sp. by Sanchiz (1998).

Here we report on a pipid fossil from Corralito, a late Miocene locality in the Urumaco Basin, Venezuela. The Neogene localities in the Urumaco Basin have so far yielded a large number of marine and continental vertebrates belonging to several major clades (Sánchez-Villagra et al., 2010; Carrillo-Briceño et al., 2015) but amphibians had not been reported to date. Most of the continental taxa retrieved are large sized, some being 'gigantic', such as the crocodilians Gryposuchus and Purussaurus, the turtle Stupendemys and the rodent Phoberomys (among others, SánchezVillagra et al., 2010; Scheyer et al., 2013). Prospection in the Urumaco Basin carried out in November 2013 yielded few continental vertebrates of small size, including the single amphibian remain that is here described and discussed. Institutional acronyms: AMNH, American Museum of Natural History, New York; AMU-CURS, Colección de Paleon- 
tología de Vertebrados de la Alcaldía de Urumaco, Estado Falcón, Venezuela; MDHC, Massimo Delfino Herpetological Collection deposited at the Department of Earth Sciences, University of Turin, Italy; MLP, Museo de La Plata, La Plata, Argentina; MNHN, Muséum National d'Histoire Naturelle, Paris, France; PIMUZ, Paläontologisches Institut und Museum, Universität Zürich, Switzerland.

\section{SYSTEMATIC PALEONTOLOGY}

\author{
ANURA Fischer von Waldheim, 1813 \\ PIPIDAE Gray, 1825 \\ PIPINAE Gray, 1825
}

Pipa Laurenti, 1768

cf. Pipa sp.

Figure 1.1-3

Material. AMU-CURS-726: fused sacral vertebra and urostyle. Locality. Corralito Locality, Urumaco, Falcón State, Venezuela (Scheyer et al., 2013).

Stratigraphy and Age. Lower Member of the Urumaco Formation, late Miocene (Quiroz and Jaramillo, 2010).

Description. The preserved portion of the fused sacrum and urostyle is $25.2 \mathrm{~mm}$ long (Fig. 1.1-3). The compound element is incomplete and its bone surface is moderately to strongly damaged. However, the characters listed below are clearly present: 1) laminar and anteroposteriorly distally expanded sacral diapophyses developed on a rather horizontal surface and laterally incomplete (maximum width of the preserved portion is $14.6 \mathrm{~mm})$; 2) sacral sagittal dorsal ridge, the neural crest, merging posteriorly with the dorsal crest (crista dorsalis) of the urostyle; 3 ) sacral centrum ventrally flat and rather broad; 4) neural canal of the sacral vertebra relatively small; 5) presence of a broad spinal foramen on each side of the fossil, below the expanded diapophyses. The dorsal surface of each sacral diapophysis has the remnants of a ridge placed close to the posteromedial edge of the bone; the two ridges are rather symmetric and diverge from each other at an angle of about $90^{\circ}$. The shapes of the articular surfaces of the sacral prezygapophyses as well as that of the sacral centrum cannot be evaluated with confidence.

Identification. Despite the poor preservation of AMU-CURS726 several characters are available and useful for its iden- tification. The fact that the sacrum and the urostyle are fused to each other might indicate referral to the Pipidae, although this character occurs in other American taxa, such as some pelobatoids (Cannatella and Trueb, 1988a,b; Báez and Trueb, 1997) and some bufonids (e.g., Cannatella, 1986; Chaparro et al., 2007; Páez-Moscoso et al., 2011). In the only living American pelobatoids, the Scaphiopodidae, the expanded sacral diapophyses do not bear ridges on the dorsal surface, close to their posteromedial edges, as shown for example by Scaphiopus holbrooki (AMNH A-16603, A-58186) and Spea multiplicata (AMNH A-56289, A-62560, A-177074, A-177075), whose diapophyses are clearly tilted dorsally and not nearly perpendicular with respect to the sagittal plane of the skeletal element as in AMU-CURS-726. Therefore, pelobatoids can be excluded on a morphological basis and not only for biogeographic reasons. The sacral morphology of most Neotropical bufonids has not been described in detail, but at least the sacral diapophyses of two species with fused sacrum and urostyle are dorsally devoid of a ridge close to the posteromedial edge (Chaparro et al., 2007; Páez-Moscoso et al., 2011) and hence clearly not congruent with AMU-CURS-726.

Among pipids, the presence of a neural crest on the sacral vertebra allows us to exclude the Xenopodinae (Cannatella and Trueb, 1988a; occasionally present in Xenopus according to Báez et al., 2008), limiting the options to the Pipinae. Many members of Pipinae have a sacral neural crest: it is present in Hymenochirus and Pseudhymenochirus (Cannatella and Trueb, 1988b) and at least in most Pipa species (where it is variably present according to Báez et al., 2008). Moreover, the presence of a scar, interpreted here as evidence for the former occurrence of a posteromedial ridge on the dorsal surface of each sacral diapophysis of AMUCURS-726, excludes its referral to Hymenochirus and Pseudhymenochirus (Cannatella and Trueb, 1988b: fig. 3) and further confirms the exclusion of Xenopus (Xenopus laevis AMNH A-72534, A-177084, A-177085, A-177086, A-177087; including Silurana, see Báez et al., 2008: fig. 3D). The presence of this character among the seven species of Pipa is not universal. It seems to be consistently present in Pipa pipa (AMNH A-51645, A-57989, A-58443; MDHC 440; MNHN 1882-461; Fig. 1.4,5), but absent in Pipa arrabali (AMNH A51175), Pipa aspera (see Trueb and Massemin, 2001: fig. 4B, but the drawing might be too schematic to show the sacral 


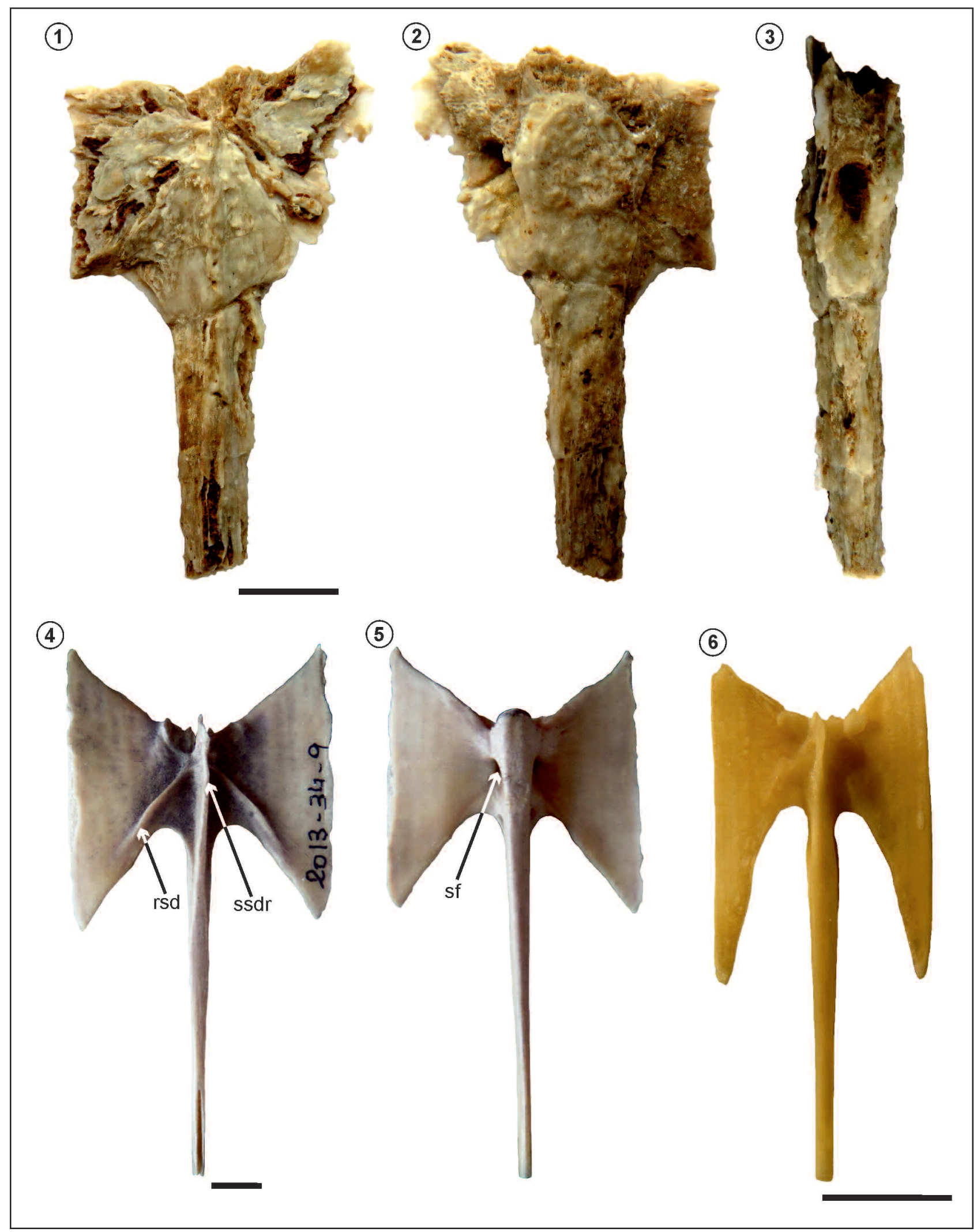

Figure 1. 1-3, cf. Pipa sp. AMU-CURS-726 from the late Miocene of Corralito (Urumaco Basin), fused sacrum and urostyle in dorsal, ventral, and right lateral views; 4-5, Pipa pipa MNHN 1882-461, fused sacrum and urostyle in dorsal and ventral views; 6, Pipa parva PIMUZ A/II 118, fused sacrum and urostyle in dorsal and ventral views. Abbreviations: rsd, ridge on sacral diapophysis; ssdr, sacral sagittal dorsal ridge; sf, spinal foramen. Scale bars $=5 \mathrm{~mm}$. 
ridges), Pipa carvalhoi (Báez et al., 2008: fig. 3F), Pipa myersi (Trueb, 1984: fig. 5) and Pipa parva (Fig. 1.6; PIMUZ A/II 118; Báez et al., 2008: fig. 3E). Samples of Pipa snethlageae were not available for this study and apparently not described or figured in the literature. As for the extinct pipids from South America, analogous ridges occur in Shelania pascuali from the Eocene of Patagonia, which is currently considered a Xenopodinae (Estes, 1975; Báez and Trueb, 1997; Báez et al., 2008; Gómez, 2016). This taxon, however, is characterized by the absence of a mid-dorsal crest (see for example Báez et al., 2008: fig. 3C) unlike AMU-CURS-726 and thus they do not represent the same taxon.

For the sake of completeness, AMU-CURS-726 can also be compared with the only post-Paleogene fossil pipids described from South America, from the Pleistocene of Argentina (Báez et al., 2008, 2012). The material from Daireaux consists of a single ilium referred to a stem Xenopodinae, but the one from Centinela del Mar includes MLP 04-V-2-220, an incomplete sacrum fused with the urostyle whose identification and relationships are still to be determined based on additional material because of the incongruent suite of characters (Báez et al., 2008). However, the ridge on the sacral diapophyses are not described nor evident in the available drawing of MLP 04-V-2-220 (Báez et al., 2008: fig. 3A).

Because of the presence of a mid-dorsal crest and ridges on the diapophyses, the pipid from Corralito is therefore referred to Pipa (as cf. Pipa sp.), pending the discovery of additional material from the same locality that might help to evaluate its phylogenetic relationships.

It is not possible to analyze the relationships of AMUCURS-726 because even if the characters currently applied to explore the phylogenetic relationships among the extinct and extant pipids are highly detailed and numerous, very few of them refer to the sacrum-urostlyle complex (9 out of 165 characters used by Gómez, 2016) and most of them cannot be evaluated on AMU-CURS-726 because of its poor preservation.

\section{DISCUSSION AND CONCLUSIONS}

Recent investigations indicate that crown-group pipids were already diversified into three lineages by the Late Cretaceous (Cannatella, 2015; Gómez, 2016), but the contribution of palaeontology to the evolutionary history of the
South American Pipa is virtually null, since the only fossils putatively referred to this genus come from an undetermined Quaternary of Brasil and were reported (not figured or described) as identical to that of extant Pipa (Liais, 1872). This is quite surprising for a clade of anurans that is morphologically highly derived, with a well-known osteology (e.g., Trueb et al., 2000) and that is therefore potentially easily identifiable.

The material from the late Miocene of northern Venezuela here referred to Pipa, besides being the first land microvertebrate reported for the Urumaco Formation, contributes to partly fill the gap of the South American pipinae. Being represented by a single, poorly-preserved skeletal element, its bearing on the evolutionary history of this clade is currently minimal, but testifies that the Urumaco Basin could potentially provide more informative remains.

Pipa currently inhabits Venezuela and even the State of Falcón with the species Pipa parva (Mijares-Urrutia and Arends, 2000). AMU-CURS-726 is not referable to Pipa parva primarily because the latter lacks the ridge on the sacral diapophyses, but also because this taxon has, as indicated by its name, a small size, whereas the size and the few available characters of the fossil from Corralito are consistent with Pipa pipa. At present, the latter has a broad range in the Amazon Basin, including Venezuela (IUCN SSC Amphibian Specialist Group, 2015), but not in the now arid region of the Sate of Falcón where the Urumaco Basin is located. However, as summarized by Scheyer et al. (2013, p. 7), "[palaeoenvironmental reconstructions based on palynofloras from the Urumaco Formation suggest a continuation of the Amazonian forest into northwestern Venezuela during the Miocene, with the faunal context including marginal marine, freshwater and continental vertebrates]". The possible presence of largesized Pipa in the Urumaco Basin could represent a further evidence of such relationship with the Amazonian Basin, before tectonic events leading to the uplift of northern Andes and consequently changes in the course of rivers, as well as climatic changes, disrupted such relationship (Hoorn et al., 2010; Pimiento et al., 2017).

\section{ACKNOWLEDGMENTS}

All the students and colleagues who attended the fieldwork campaign of November 2013 are thanked for their work. S. Bailon (Paris), D.A. Kizirian (New York) and F. Glaw (Munich) kindly permitted access to extant comparative material under their care. G. Rivas 
(Maracaibo) generously organised the comparative material of $P$. parva, J. Gardner (Drumheller) provided relevant literature and J.D. Carrillo-Briceño (Zurich) provided curatorial and technical assistance. A. Villa (Turin) is thanked for the photo of extant P. pipa of Fig. 1. Massimo Delfino was supported by Fondi di Ateneo dell'Università di Torino (2015-2016). The Handling Editor A.M. Báez and R.O. Gómez (Buenos Aires), as well as an anonymous reviewer significantly improved the manuscript.

\section{REFERENCES}

Báez, A.M. 1996. The fossil record of the Pipidae. In: R.C. Tinsley, and H.R. Kobel, (Eds.), The Biology of Xenopus. Symposia of the Zoological Society of London, 68: 329-347.

Báez, A.M., and Trueb, L. 1997. Redescription of the Paleogene Shelania pascuali and its bearing on the relationships of fossil and recent pipoid frogs. Scientific Papers, Natural History Museum, The University of Kansas 4: 1-41.

Báez, A.M., Scanferla, C.A., Agnolin, F.L, Cenizo, M., and De Los Reyes, M. 2008. Pipid frog from the Pleistocene of the Pampas of Southern South America. Journal of Vertebrate Paleontology 28: 1195-1198.

Báez, A.M., Gómez, R.O., and Taglioretti, M.L. 2012. The archaic ilial morphology of an enigmatic pipid frog from the upper Pleistocene of the South American pampas. Journal of Vertebrate Paleontology 32: 304-314.

Cannatella, D.C. 1986. A new genus of bufonid (Anura) from South America, and phylogenetic relationships of the Neotropical genera. Herpetologica 42: 197-205.

Cannatella, D.C. 2015. Xenopus in space and time: fossils, node calibrations, tip-dating, and paleobiogeography. Cytogenetic and Genome Research 145: 283-301.

Cannatella, D.C., and Trueb, L. 1988a. Evolution of pipoid frogs: intergeneric relationships of the aquatic frog family Pipidae (Anura). Zoological Journal of the Linnean Society 94: 1-38.

Cannatella, D.C., and Trueb, L. 1988b. Evolution of pipoid frogs: morphology and phylogenetic relationships of Pseudhymenochirus. Journal of Herpetology 22: 439-456.

Carrillo-Briceño, J.D., Maxwell, E., Aguilera, O.A., Sánchez, R., and Sánchez-Villagra, M.R. 2015. Sawfishes and other elasmobranch assemblages from the Mio-Pliocene of the South Caribbean (Urumaco Sequence, Northwestern Venezuela). PLoS ONE 10: e0139230.

Chaparro, J.C., Pramuk, J.B., and Gluesenkamp, A.G. 2007. A new species of arboreal Rhinella (Anura: Bufonidae) from cloud forest of southeastern Peru. Herpetologica 63: 203-212.

Estes, R. 1975. Fossil Xenopus from the Paleocene of South America and the zoogeography of pipid frogs. Herpetologica 31: 263-278.

Fischer von Waldheim, G. 1813. Zoognosia tabulis synopticis illustrata, in usum praelectionorum Academiae Imperialis Medico-Chirurgicae Mosquensis edita. Third edition. Nicolai Sergeidis Vsevolozsky, Moscow, $465 \mathrm{p}$.

Frost, D.R. 2017. Amphibian Species of the World: an Online Reference. Version 6.0 (July 3, 2017). Electronic Database accessible at http://research.amnh.org/herpetology/amphibia/index.html. American Museum of Natural History, New York, USA.

Gómez, R.O. 2016. A new pipid frog from the Upper Cretaceous of Patagonia and early evolution of crown-group Pipidae. Cretaceous Research 62: 52-64.

Gray, J.E. 1825. A synopsis of the genera of reptiles and Amphibia, with a description of some new species. Annals of Philosophy 26: 193-217.

Hoorn, C., Wesselingh, F.P., ter Steege, H., Bermudez, M.A., Mora,
A., Sevink, J., Sanmartín, I., Sanchez-Meseguer, A., Anderson, C.L., Figueiredo, J.P., Jaramillo, C., Riff, D., Negri, F.R., Hooghiemstra, H., Lundberg, J., Stadler, T., Särkinen, T., and Antonelli, A. 2010. Amazonia through time: Andean uplift, climate change, landscape evolution, and biodiversity. Science 330: 927-931.

IUCN SSC Amphibian Specialist Group, 2015. Pipa pipa. The IUCN Red List of Threatened Species 2015: e.T58163A61414791.

Laurenti, J.N. 1768. Specimen medicum, exhibens synopsin reptilium emendatum cum experimentis circa venena et antidota reptilium austriacorum.: J. T. de Trattnern. Wien, $214 \mathrm{p}$.

Liais, E. 1872. Climats, géologie, faune et géographie botanique du Brésil. Garnier, Paris, 640 p.

Mijares-Urrutia, A., and Arends, A. 2000. Herpetofauna of Estado Falcón, northwestern Venezuela: a checklist with geographical and ecological data. Smithsonian Herpetological Information Service 123: 1-30.

Páez-Moscoso, D.J., Guayasamin, J.M., and Yanez-Munoz, M. 2011. A new species of Andean toad (Bufonidae, Osornophryne) discovered using molecular and morphological data, with a taxonomic key for the genus. ZooKeys 108: 73-97.

Pimiento, C., Griffin, J.N., Clements, C.F., Silvestro, D., Varela, S., Uhen, M.D., and Jaramillo, C. 2017. The Pliocene marine megafauna extinction and its impact on functional diversity. Nature Ecology \& Evolution, 1. doi:10.1038/s41559-017-0223-6.

Quiroz, L.I., and Jaramillo, C.A. 2010. Stratigraphy and sedimentary environments of Miocene shallow to marginal marine deposits in the Urumaco trough, Falcón basin, western Venezuela. In: M.R Sánchez-Villagra, O.A. Aguilera, and A.A. Carlini (Eds.), Urumaco and Venezuelan Paleontology. The Fossil Record of the Northern Neotropics. Indiana University Press, Bloomington \& Indianapolis, p. 153-172.

Sánchez-Villagra, M.R., Aguillera, O.A., and Carlini, A.A. (Eds.) 2010. Urumaco and Venezuelan Paleontology. Indiana University Press, Bloomington \& Indianapolis, 290 p.

Sanchiz, B. 1998. Salientia. In: Handbuch der PaläoherpetologieEncyclopedia of Paleoherpetology. Part 4. Verlag Friedrich Pfeil, München, $275 \mathrm{p}$.

Scheyer, T.M., Aguilera, O.A., Delfino, M., Fortier, D.C., Carlini, A.A., Sánchez, R., Carrillo-Briceño, J., Quiroz, L., and Sánchez-Villagra, M.R. 2013. Crocodylian diversity peak and extinction in the late Cenozoic of the northern Neotropics. Nature Communications 4: 1907.

Tinsley, R.C., Stott, L.C., Viney, M.E., Mable, B.K., and Tinsley, M.C. 2015. Extinction of an introduced warm-climate alien species, Xenopus laevis, by extreme weather events. Biological Invasions 17: 3183-3195.

Trueb, L. 1984. Description of a new species of Pipa (Anura: Pipidae) from Panama. Herpetologica 3: 225-234.

Trueb, L., and Massemin, D. 2001. The osteology and relationships of Pipa aspera (Amphibia: Anura: Pipidae), with notes on its natural history in French Guiana. Amphibia-Reptilia 22: 33-54.

Trueb, L., Púgener, L.A., and Maglia, A.M. 2000. Ontogeny of the Bizarre: an osteological description of Pipa pipa (Anura: Pipidae), with an account of skeletal development in the species. Journal of Morphology 243: 75-104.

doi: 10.5710/AMGH.04.10.2017.3136

Submitted: July $7^{\text {th }}, 2016$

Accepted: October $4^{\text {th }}, 2017$

Published online: October $6^{\text {th }}, 2017$ 